\title{
The Method of Learning and Its Effect on Memory
}

\author{
Pamella Sylvia Ann Kelasi ${ }^{1 *}$
}

\section{ABSTRACT}

Aim: To find out the relation between the types of learning and memory. Objective: To conclude that the types of learning relates to short term and long term memory. Background and Reason: Memory is the ability to encode, store, retain and subsequently recall information and past experiences in the human brain. Individuals differ in their level of memory. Its really fascinating to know the uniqueness in their memory. So the reason behind this research is to find out the uniqueness and methods followed by the individuals in their learning process. This study can also help in giving ideas to improve the memory and thus learning methods among individuals.

Keywords: Behavior, Long-term, Memory, Learning, Methods

Learning is a process experience is needed and this gives long-term changes in behavior potential. Behavior potential can be define as the possible behavior of an individual and not the actual behavior. Factors that influence learning process are effects of the environment, conditioning, reinforcement, and etc.[1]

The father of learning is Socrates which dated back in 469-399 B.C. He introduced a method of learning that is now referred to as piloting. If is basically using our own reason to find an answer. [2] [3] Hermann Ebbinghaus (1850-1909) continued the study of learning in 1885. He did a study on memory that is free from meaningful associations. He found out that by practicing and repetition, one can remember better.[2]

In the early 1900s, there was a Russian physiologist named Ivan Petrovich Pavlov (1849-1936). He contributed on learning theories based on an experiment involving a dog and food. He conducted the experiment and proved his thesis true that dog can salivate by just the presentation of the sound of a bell. This method is known as the classical conditioning.[1]

Nowadays, individuals tend to have their own style or method of learning. For example, some like to self-study, study in a group and studying using visuals. Each method has their own effect on memory of individuals. Self-study is associated with only one individual without interacting

\footnotetext{
${ }^{1}$ Psychology, Student, Saveetha Dental College, Chennai, India

*Responding Author

(C) 2016 I P Kelasi; licensee IJIP. This is an Open Access Research distributed under the terms of the Creative Commons Attribution License (http://creativecommons.org/licenses/by/2.0), which permits unrestricted use, distribution, and reproduction in any Medium, provided the original work is properly cited.
} 
with other people. These group of people usually cannot tolerate noisy environment.[4] Group study involves a group of people studying together. These group of people can exchange their materials of study to each other.[5] Visual learning is a method of learning where drawings are important. They learn by drawing pictures, making diagrams, do concept mapping and ect.[6]

Memory is the ability of individual to encode, store, retain and subsequently recall information and past experiences in the human brain. It can the thought of in general terms of using past experience to influence current behaviour. There are three types of memory which is sensory memory, short-term memory, and ling-term memory.[7]

Sensory memory is the shortest term of memory. It is stimulated by our five senses which are sight, smell, hearing, taste and touch. It decays or degrades very fast in the range of 200-500 milliseconds. There are three types of sensory memory which are iconic memory ( visual stimuli) , echoic memory ( hearing stimuli ), and hap tic memory ( touch stimuli ).

Short term memory acts as a temporary recall of information. It can hold only a small amount of information, around 7 items or less. Short tern memory can be converted into long term memory. Long term memory can store larger quantities of information for unlimited duration. It can divided into declarative memory and procedural memory.

\section{MATERIALS AND METHODS}

The study was done as a questionnaire-based study among I BDS students of Saveetha Dental College. A total of 50 students participated in the survey. All the students were provided with questions regarding their methods of learning which is divided into 3 types : Type 1 ( Self-study ), Type 2 ( Group study ) and Type 3 ( Visual learning ). The students are required to answer each question that best describe their methods of learning based on these 3 types of methods of learning. Each question consist of answers such as: strongly agree which carry 5 marks, agree that carry 4 marks, unsure with 3 marks, disagree that carry 2 marks and strongly disagree with 1 mark. At the end of the survey, marks is calculated according to each type.

\begin{tabular}{|l|l|l|l|}
\hline STUDENT'S NO. & TYPE 1 & TYPE 2 & TYPE 3 \\
\hline $\mathbf{1 .}$ & 20 & 15 & 22 \\
\hline $\mathbf{2 .}$ & 10 & 15 & 17 \\
\hline $\mathbf{3 .}$ & 21 & 17 & 24 \\
\hline $\mathbf{4 .}$ & 15 & 20 & 15 \\
\hline $\mathbf{5 .}$ & 21 & 18 & 20 \\
\hline $\mathbf{6 .}$ & 18 & 11 & 19 \\
\hline $\mathbf{7 .}$ & 17 & 12 & 17 \\
\hline $\mathbf{8 .}$ & 13 & 15 & 14 \\
\hline $\mathbf{9 .}$ & 21 & 16 & 18 \\
\hline $\mathbf{1 0 .}$ & 22 & 13 & 15 \\
\hline $\mathbf{1 1 .}$ & 14 & 16 & 18 \\
\hline $\mathbf{1 2 .}$ & 22 & 17 & 24 \\
\hline
\end{tabular}

(C) The International Journal of Indian Psychology, ISSN 2348-5396 (e)| ISSN: 2349-3429 (p) | 146 
The Method of Learning and Its Effect on Memory

\begin{tabular}{|c|c|c|c|}
\hline STUDENT'S NO. & TYPE 1 & TYPE 2 & TYPE 3 \\
\hline 13. & 21 & 16 & 20 \\
\hline 14. & 20 & 18 & 20 \\
\hline 15. & 17 & 16 & 19 \\
\hline 16. & 19 & 15 & 18 \\
\hline 17. & 14 & 19 & 18 \\
\hline 18. & 20 & 12 & 21 \\
\hline 19. & 25 & 13 & 25 \\
\hline 20. & 18 & 17 & 18 \\
\hline 21. & 19 & 16 & 20 \\
\hline 22. & 17 & 14 & 19 \\
\hline 23. & 17 & 20 & 16 \\
\hline 24. & 20 & 19 & 20 \\
\hline 25. & 19 & 15 & 22 \\
\hline 26. & 23 & 11 & 19 \\
\hline 27. & 19 & 16 & 20 \\
\hline 28. & 19 & 13 & 17 \\
\hline 29. & 21 & 18 & 20 \\
\hline 30. & 15 & 15 & 15 \\
\hline 31. & 20 & 16 & 19 \\
\hline 32. & 14 & 21 & 18 \\
\hline 33. & 14 & 15 & 12 \\
\hline 34. & 12 & 13 & 13 \\
\hline 35. & 19 & 15 & 19 \\
\hline 36. & 17 & 14 & 20 \\
\hline 37. & 17 & 17 & 20 \\
\hline 38. & 18 & 15 & 16 \\
\hline 39. & 15 & 21 & 17 \\
\hline 40. & 15 & 12 & 11 \\
\hline 41. & 15 & 12 & 21 \\
\hline 42. & 21 & 13 & 17 \\
\hline 43. & 15 & 13 & 18 \\
\hline 44. & 18 & 12 & 17 \\
\hline 45. & 14 & 17 & 18 \\
\hline 46. & 15 & 18 & 17 \\
\hline 47. & 19 & 21 & 22 \\
\hline 48. & 18 & 18 & 16 \\
\hline 49. & 16 & 17 & 13 \\
\hline 50. & 17 & 19 & 22 \\
\hline
\end{tabular}

(C) The International Journal of Indian Psychology, ISSN 2348-5396 (e)| ISSN: 2349-3429 (p) | 147 
The Method of Learning and Its Effect on Memory

Total Score

\begin{tabular}{|l|l|l|l|}
\hline & TYPE 1 & TYPE 2 & TYPE 3 \\
\hline TOTAL SCORE & 886 & 787 & 916 \\
\hline
\end{tabular}

Average Score

\begin{tabular}{|l|l|l|l|}
\hline & TYPE 1 & TYPE 2 & TYPE 3 \\
\hline AVERAGE SCORE & 17.72 & 15.74 & 18.32 \\
\hline
\end{tabular}

\section{RESULT}

\section{Scores Of Each Student}

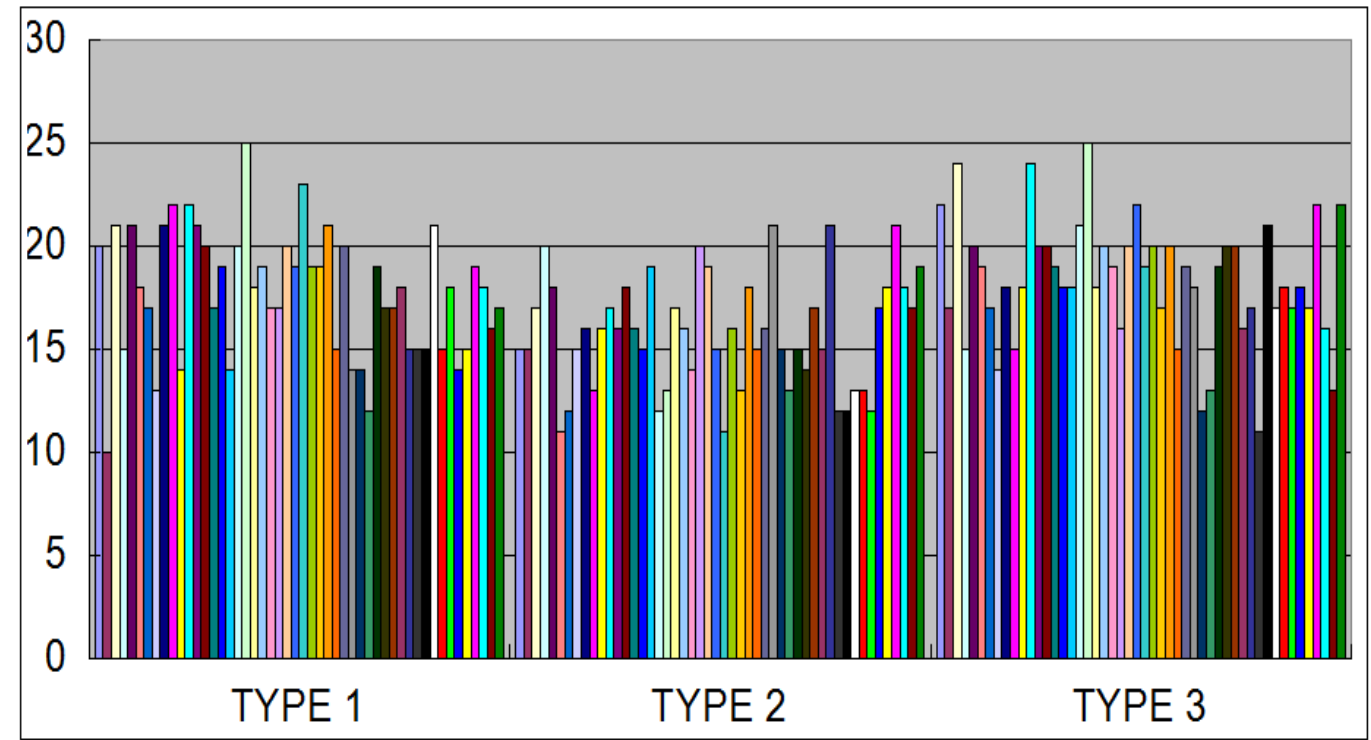

\section{Total Score}

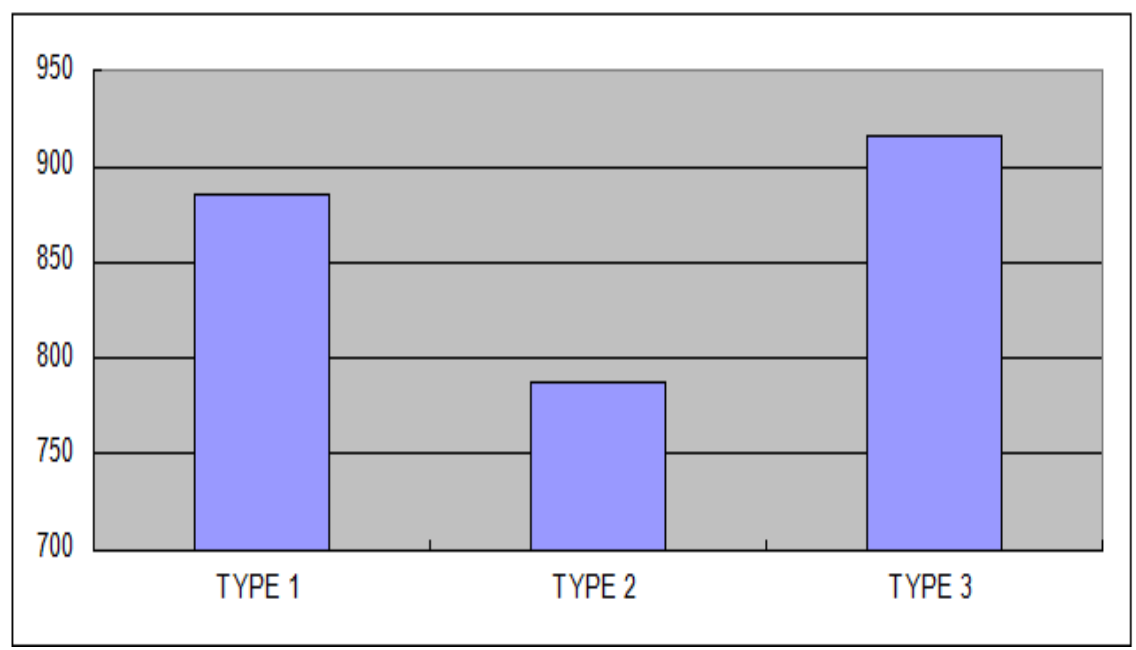

(c) The International Journal of Indian Psychology, ISSN 2348-5396 (e)| ISSN: 2349-3429 (p) | 148 
The Method of Learning and Its Effect on Memory

\section{Average Score}

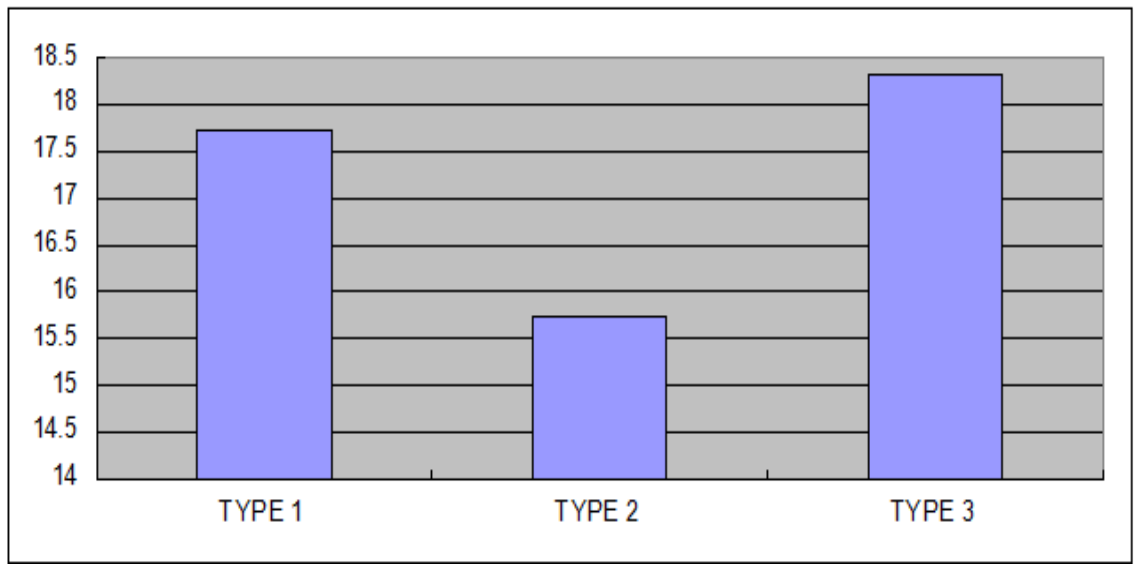

Type 1

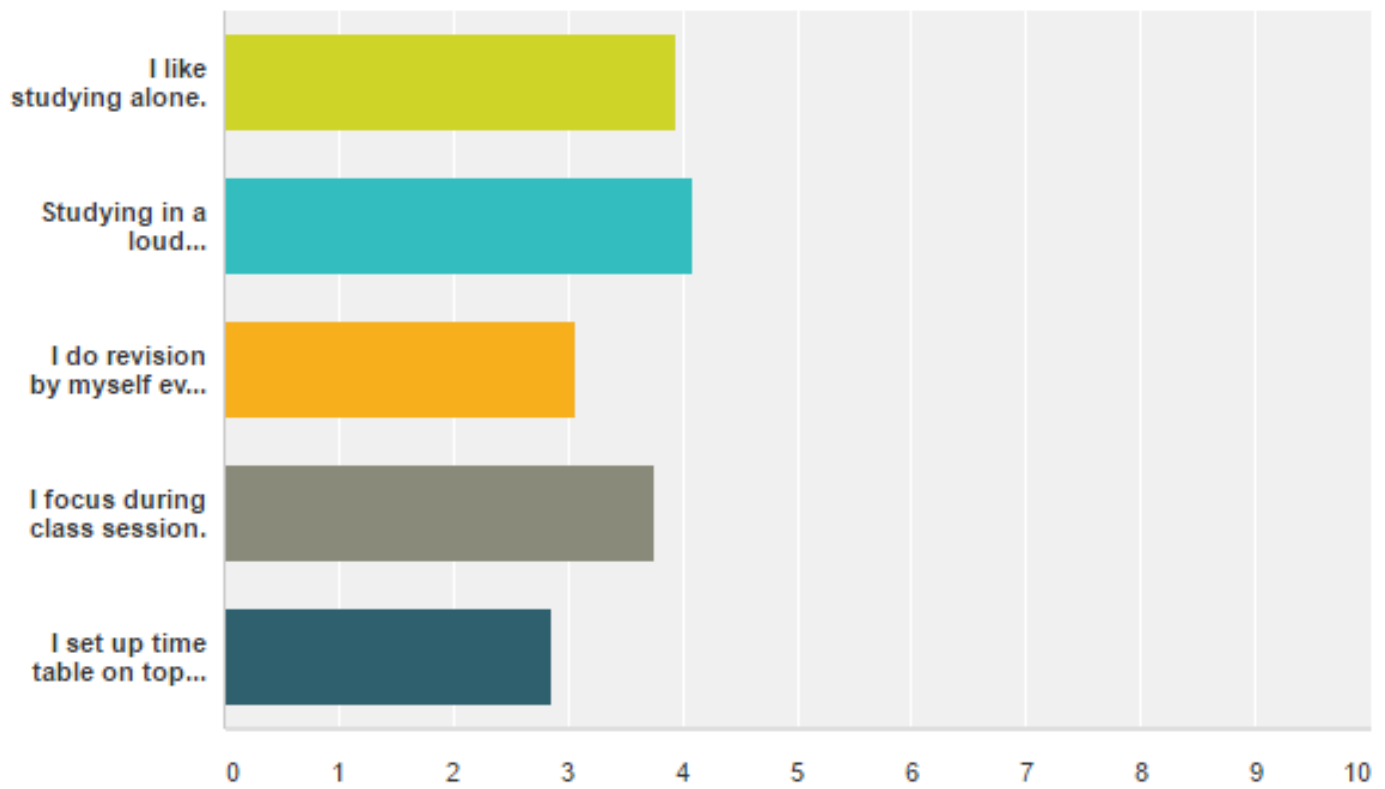

(c) The International Journal of Indian Psychology, ISSN 2348-5396 (e)| ISSN: 2349-3429 (p) | 149 
The Method of Learning and Its Effect on Memory

\begin{tabular}{|c|c|c|c|c|c|c|c|}
\hline$\nabla$ & $\begin{array}{l}\text { Strongly } \\
\text { disagree }\end{array}$ & Disagree $\vee$ & Unsure - & Agree $>$ & $\begin{array}{l}\text { Strongly } \\
\text { agree }\end{array}$ & Total & $\begin{array}{l}\text { Weighted } \\
\text { Average }\end{array}$ \\
\hline $\begin{array}{l}\text { I like } \\
\text { studying } \\
\text { alone. }\end{array}$ & $\begin{array}{r}4.00 \% \\
2\end{array}$ & $\begin{array}{r}6.00 \% \\
3\end{array}$ & $\begin{array}{r}6.00 \% \\
3\end{array}$ & $\begin{array}{r}60.00 \% \\
30\end{array}$ & $\begin{array}{r}24.00 \% \\
12\end{array}$ & 50 & 3.94 \\
\hline $\begin{array}{l}\text { Studying in } \\
\text { a loud } \\
\text { environment } \\
\text { bothers me. }\end{array}$ & $\begin{array}{r}6.00 \% \\
3\end{array}$ & $\begin{array}{r}6.00 \% \\
3\end{array}$ & $\begin{array}{r}10.00 \% \\
5\end{array}$ & $\begin{array}{r}28.00 \% \\
14\end{array}$ & $\begin{array}{r}50.00 \% \\
25\end{array}$ & 50 & 4.10 \\
\hline $\begin{array}{l}\text { I do revision } \\
\text { by myself } \\
\text { every day. }\end{array}$ & $\begin{array}{r}8.00 \% \\
4\end{array}$ & $\begin{array}{r}24.00 \% \\
12\end{array}$ & $\begin{array}{r}32.00 \% \\
16\end{array}$ & $\begin{array}{r}26.00 \% \\
13\end{array}$ & $\begin{array}{r}10.00 \% \\
5\end{array}$ & 50 & 3.06 \\
\hline $\begin{array}{l}\text { I focus } \\
\text { during class } \\
\text { session. }\end{array}$ & $\begin{array}{r}0.00 \% \\
0\end{array}$ & $\begin{array}{r}4.00 \% \\
2\end{array}$ & $\begin{array}{r}36.00 \% \\
18\end{array}$ & $\begin{array}{r}40.00 \% \\
20\end{array}$ & $\begin{array}{r}20.00 \% \\
10\end{array}$ & 50 & 3.76 \\
\hline $\begin{array}{l}\text { I set up time } \\
\text { table on } \\
\text { topics to } \\
\text { study } \\
\text { everyday. }\end{array}$ & $\begin{array}{r}16.00 \% \\
8\end{array}$ & $\begin{array}{r}22.00 \% \\
11\end{array}$ & $\begin{array}{r}30.00 \% \\
15\end{array}$ & $\begin{array}{r}24.00 \% \\
12\end{array}$ & $\begin{array}{r}8.00 \% \\
4\end{array}$ & 50 & 2.86 \\
\hline
\end{tabular}

Type 2

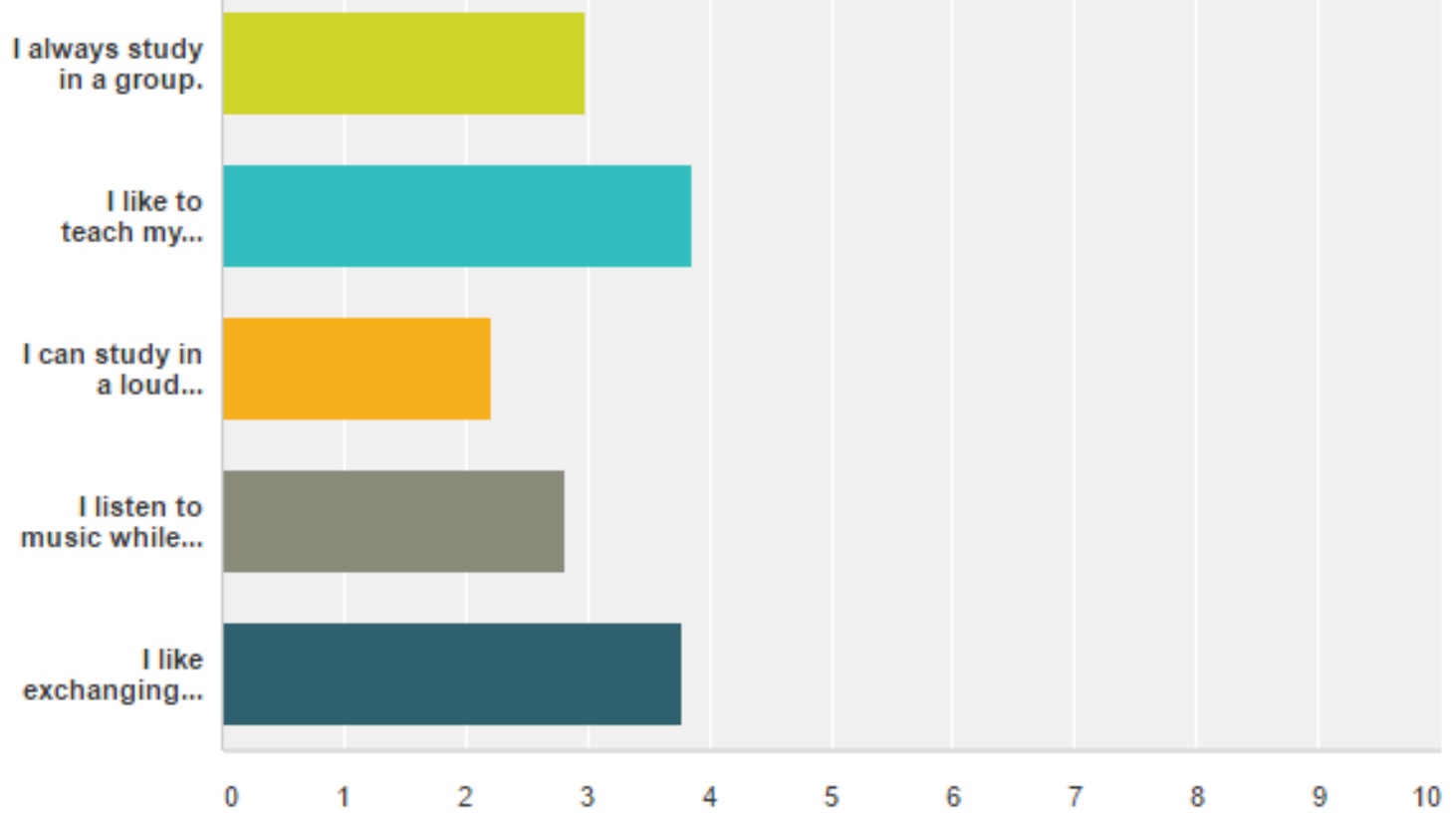

(c) The International Journal of Indian Psychology, ISSN 2348-5396 (e)| ISSN: 2349-3429 (p) | 150 
The Method of Learning and Its Effect on Memory

\begin{tabular}{|c|c|c|c|c|c|c|c|}
\hline$\nabla$ & $\begin{array}{l}\text { Strongly } \\
\text { disagree }\end{array}$ & Disagree $\nabla$ & Unsure $\vee$ & Agree $\nabla$ & $\begin{array}{l}\text { Strongly } \\
\text { agree }\end{array}$ & Total ₹ & $\begin{array}{l}\text { Weighted } \\
\text { Average }\end{array}$ \\
\hline $\begin{array}{l}\text { I always } \\
\text { study in a } \\
\text { group. }\end{array}$ & $\begin{array}{r}4.00 \% \\
2\end{array}$ & $\begin{array}{r}30.00 \% \\
15\end{array}$ & $\begin{array}{r}36.00 \% \\
18\end{array}$ & $\begin{array}{r}24.00 \% \\
12\end{array}$ & $\begin{array}{r}6.00 \% \\
3\end{array}$ & 50 & 2.98 \\
\hline $\begin{array}{l}\text { I like to teach } \\
\text { my friends. }\end{array}$ & $\begin{array}{r}4.00 \% \\
2\end{array}$ & $\begin{array}{r}6.00 \% \\
3\end{array}$ & $\begin{array}{r}16.00 \% \\
8\end{array}$ & $\begin{array}{r}48.00 \% \\
24\end{array}$ & $\begin{array}{r}26.00 \% \\
13\end{array}$ & 50 & 3.86 \\
\hline $\begin{array}{l}\text { I can study } \\
\text { in a loud } \\
\text { environment. }\end{array}$ & $\begin{array}{r}34.00 \% \\
17\end{array}$ & $\begin{array}{r}24.00 \% \\
12\end{array}$ & $\begin{array}{r}28.00 \% \\
14\end{array}$ & $\begin{array}{r}14.00 \% \\
7\end{array}$ & $\begin{array}{r}0.00 \% \\
0\end{array}$ & 50 & 2.22 \\
\hline $\begin{array}{l}\text { I listen to } \\
\text { music while } \\
\text { studying. }\end{array}$ & $\begin{array}{r}16.00 \% \\
8\end{array}$ & $\begin{array}{r}26.00 \% \\
13\end{array}$ & $\begin{array}{r}26.00 \% \\
13\end{array}$ & $\begin{array}{r}24.00 \% \\
12\end{array}$ & $\begin{array}{r}8.00 \% \\
4\end{array}$ & 50 & 2.82 \\
\hline $\begin{array}{l}\text { I like } \\
\text { exchanging } \\
\text { materials of } \\
\text { study with } \\
\text { my friends. }\end{array}$ & $\begin{array}{r}2.00 \% \\
1\end{array}$ & $\begin{array}{r}2.00 \% \\
1\end{array}$ & $\begin{array}{r}30.00 \% \\
15\end{array}$ & $\begin{array}{r}48.00 \% \\
24\end{array}$ & $\begin{array}{r}18.00 \% \\
9\end{array}$ & 50 & 3.78 \\
\hline
\end{tabular}

\section{Type 3}

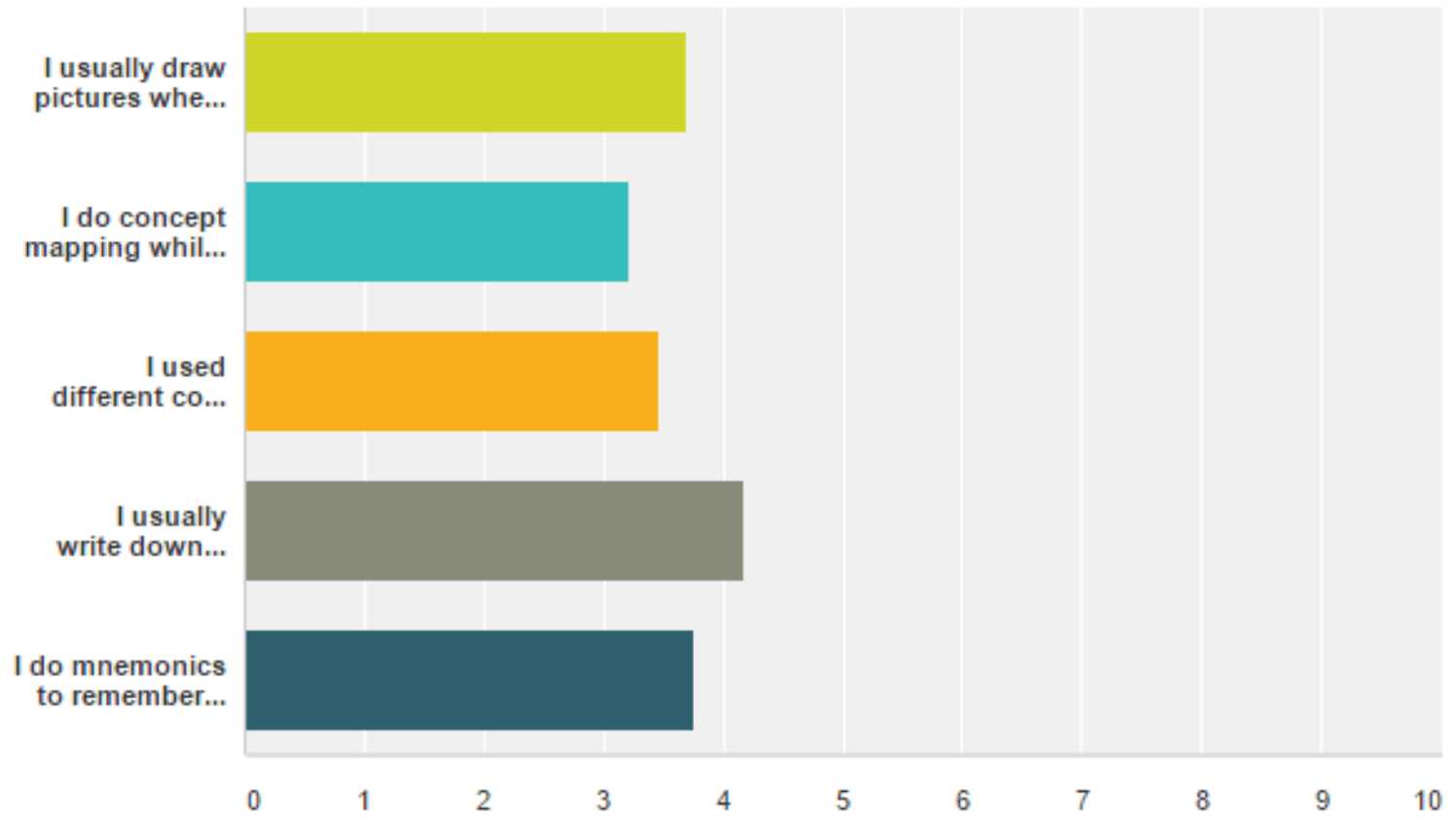

(C) The International Journal of Indian Psychology, ISSN 2348-5396 (e)| ISSN: 2349-3429 (p) | 151 
The Method of Learning and Its Effect on Memory

\begin{tabular}{|c|c|c|c|c|c|c|c|c|}
\hline & $\nabla$ & $\begin{array}{l}\text { Strongly } \\
\text { disagree }\end{array}$ & Disagree - & Unsure - & Agree & $\begin{array}{l}\text { Strongly } \\
\text { agree }\end{array}$ & Total $>$ & $\begin{array}{l}\text { Weighted } \\
\text { Average }\end{array}$ \\
\hline 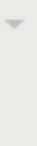 & $\begin{array}{l}\text { I usually } \\
\text { draw } \\
\text { pictures } \\
\text { when } \\
\text { studying. }\end{array}$ & $\begin{array}{r}4.00 \% \\
2\end{array}$ & $\begin{array}{r}12.00 \% \\
6\end{array}$ & $\begin{array}{r}14.00 \% \\
7\end{array}$ & $\begin{array}{r}50.00 \% \\
25\end{array}$ & $\begin{array}{r}20.00 \% \\
10\end{array}$ & 50 & 3.70 \\
\hline 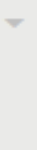 & $\begin{array}{l}\text { I do } \\
\text { concept } \\
\text { mapping } \\
\text { while } \\
\text { studying. }\end{array}$ & $\begin{array}{r}8.00 \% \\
4\end{array}$ & $\begin{array}{r}12.00 \% \\
6\end{array}$ & $\begin{array}{r}36.00 \% \\
18\end{array}$ & $\begin{array}{r}38.00 \% \\
19\end{array}$ & $\begin{array}{r}6.00 \% \\
3\end{array}$ & 50 & 3.22 \\
\hline 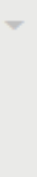 & $\begin{array}{l}\text { I used } \\
\text { different } \\
\text { color pens } \\
\text { and pencils } \\
\text { to write } \\
\text { notes. }\end{array}$ & $\begin{array}{r}4.00 \% \\
2\end{array}$ & $\begin{array}{r}18.00 \% \\
9\end{array}$ & $\begin{array}{r}20.00 \% \\
10\end{array}$ & $\begin{array}{r}44.00 \% \\
22\end{array}$ & $\begin{array}{r}14.00 \% \\
7\end{array}$ & 50 & 3.46 \\
\hline$\sim$ & $\begin{array}{l}\text { I usually } \\
\text { write down } \\
\text { words } \\
\text { while } \\
\text { studying. }\end{array}$ & $\begin{array}{r}0.00 \% \\
0\end{array}$ & $\begin{array}{r}4.00 \% \\
2\end{array}$ & $\begin{array}{r}14.00 \% \\
7\end{array}$ & $\begin{array}{r}42.00 \% \\
21\end{array}$ & $\begin{array}{r}40.00 \% \\
20\end{array}$ & 50 & 4.18 \\
\hline$\nabla$ & $\begin{array}{l}\text { I do } \\
\text { mnemonics } \\
\text { to } \\
\text { remember } \\
\text { better. }\end{array}$ & $\begin{array}{r}0.00 \% \\
0\end{array}$ & $\begin{array}{r}8.00 \% \\
4\end{array}$ & $\begin{array}{r}34.00 \% \\
17\end{array}$ & $\begin{array}{r}32.00 \% \\
16\end{array}$ & $\begin{array}{r}26.00 \% \\
13\end{array}$ & 50 & 3.76 \\
\hline
\end{tabular}

\section{Weighted Average And Total Weighted Average}

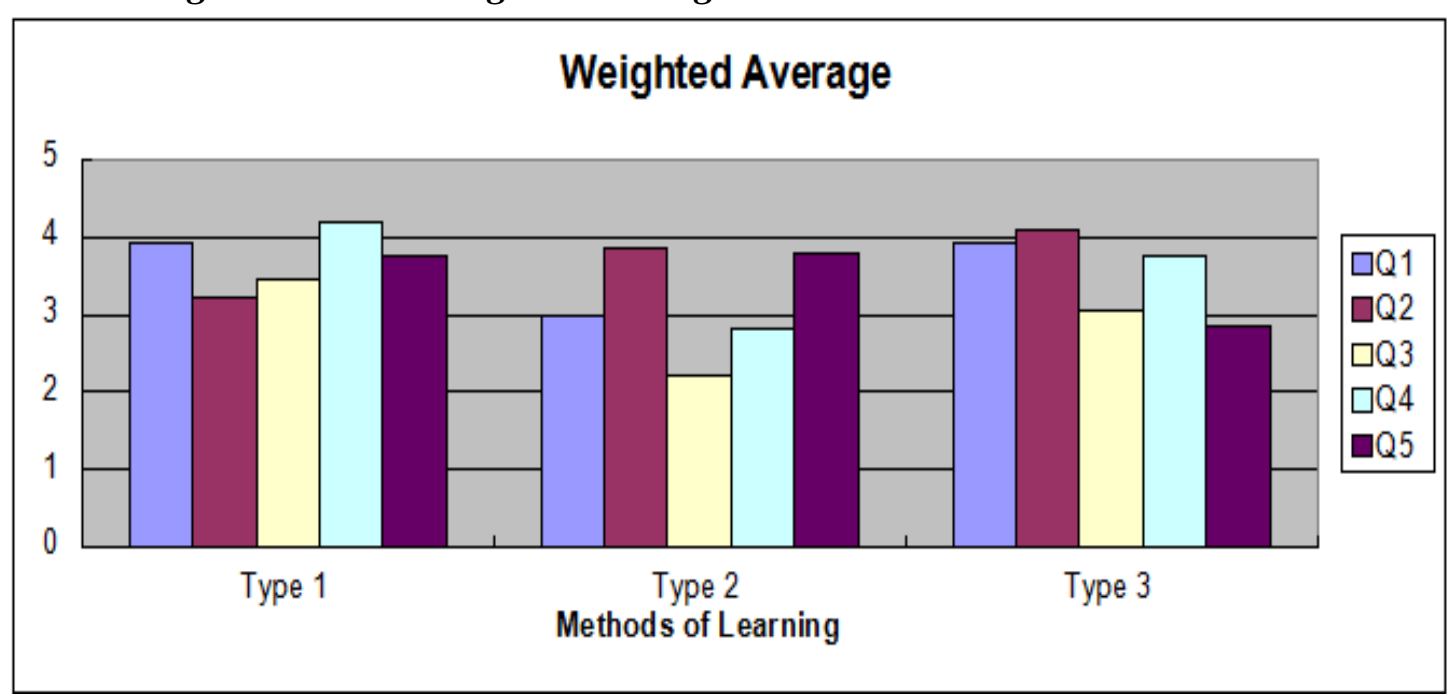

(c) The International Journal of Indian Psychology, ISSN 2348-5396 (e)| ISSN: 2349-3429 (p) | 152 


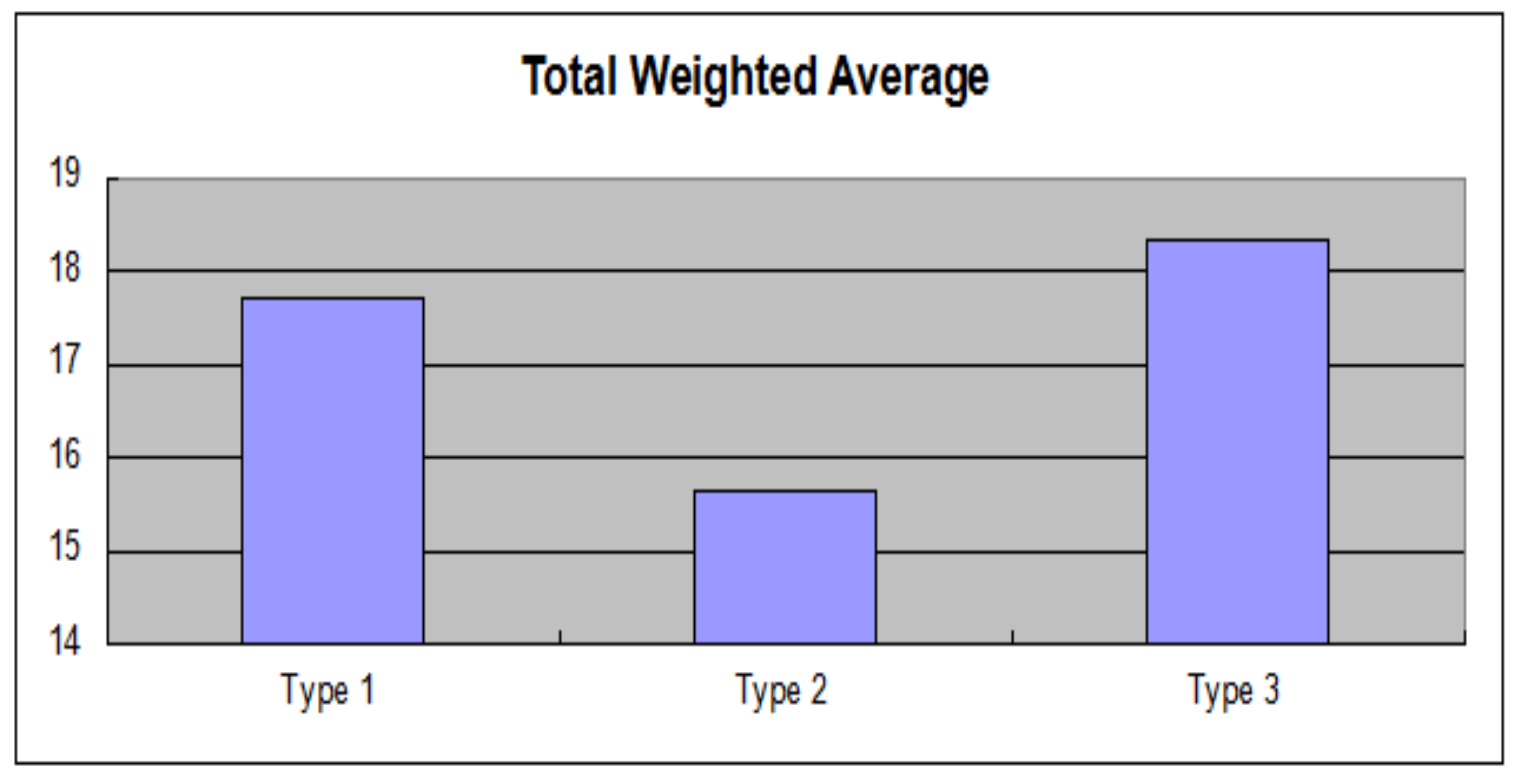

\section{DISCUSSION}

The study involved 50 students of I BDS in Saveetha Dental College to analyze their methods of learning and its effect on memory.

According to the result, a total of 18.32 is the total weighted average for visual learning making it the highest score in method of learning among the 3 methods. The second highest is self-study with a total weighted average of 17.72. Group study ranked the last with a total weighted average of 15.66 .

\begin{tabular}{|l|l|}
\hline Questions & Weighted average \\
\hline 1. I can study in a loud environment. & 2.22 \\
\hline 2. I listen to music while studying. & 2.82 \\
\hline 3. I set up time table on topics to study everyday. & 2.86 \\
\hline 4. I always study in a group & 2.98 \\
\hline 5. I do revision by myself everyday. & 3.06 \\
\hline 6. I do concept mapping while studying. & 3.22 \\
\hline 7. I used different colour pens and pencils to write notes. & 3.46 \\
\hline 8. I usually draw pictures when studying. & 3.70 \\
\hline
\end{tabular}

(c) The International Journal of Indian Psychology, ISSN 2348-5396 (e)| ISSN: 2349-3429 (p) | 153 
The Method of Learning and Its Effect on Memory

\begin{tabular}{|l|l|}
\hline 9. I focus during class session. & 3.76 \\
\hline 10. I do mnemonics to remember better. & 3.76 \\
\hline 11. I like exchanging materials of study with my friends. & 3.78 \\
\hline 12. I like to teach my friends. & 3.86 \\
\hline 13. I like studying alone. & 3.94 \\
\hline 14. Studying in a loud environment bothers me. & 4.10 \\
\hline 15. I usually write down words while studying. & 4.18 \\
\hline
\end{tabular}

The rank of weighted average according to questions are ( in ascending manner) :

This study shows that the method of learning which is visual learning is more common among students in Saveetha Dental College and less common is group study.

\section{CONCLUSION}

The three methods of learning have its own advantages and disadvantages. Example of advantage of self study is that individual can concentrate more without any distraction from anyone hence can increase their memory. The disadvantage of self-study is that individuals can have a hard time to mingle or socialize with other individuals.

As for group study, the advantage is that individuals can give their opinion and thought on how to remember the topic of learning more effectively. The disadvantage of group study is that individuals tends to be discussing things that is out of topic, eg : gossiping, chatting and etc.

The advantage of visual learning is that one can remember better when seeing and doing it. This principle is based on Chinese proverb- 'If I hear, I forget ; If I see, I remember ; If I do, I know'. In the other hand, the disadvantage of visual learning is that individuals can get tired easily when doing concept mapping and taking notes down while reading.

There are many ways to improve memory. Examples are :

- Chunking : breaks a long list of numbers or other information's into smaller, eg : a number sequence of 1-7-2-6-3-5-4 can be chunked into 172-6354.

- Sleeping : can calm our mind.

- Diet : eat brain boosting diet such as omega 3, spinach, vegetables and etc. Avoid intake of high calories food and high saturated fat foods.

- Meditation : helps to calm the mind.

- Medication : intake of medicine such as acetylcholine, nicotine and epinephrine.

- Method of loci : placing items in places that you can remember easily.

- Breath deep : this can help to increase oxygen inhalation [8][9]

(c) The International Journal of Indian Psychology, ISSN 2348-5396 (e)| ISSN: 2349-3429 (p) | 154 


\section{REFERENCES}

1."Psychology of Learning." Wikipedia. Wikimedia Foundation. Web. https://en.wikipedia.org/wiki/Psychology_of_learning

2. Marton, Ference, and Shirley Booth. Learning and Awareness. Mahwah: Lawrence Erlbaum Associates,, 1997. Google Books. Web. 8 December 2011. http://books.google.com/books?hl=en

3. Hergenhahn, B. R. An Introduction to the History of Psychology. Belmont: Thompson Learning, 2005. Web. 5 December 2011.

4. "Self-Studying: What's the Benefit and How to Do It." IvyWise RSS. Web. https://www.ivywise.com/ivywise-knowledgebase/newsletter/article/self-studying-whatsthe-benefit-and-how-to-do-it/

5.”Study Group.” Wikipedia. Wikimedia foundation .Web. https://en.wikipedia.org/wiki/Study_group

6. "Visual Learning Style: Definition \& Characteristics - Video \& Lesson Transcript | Study.com." Study.com. Web. http://study.com/academy/lesson/visual-learning-style-definition-characteristics.html

7. "Memory." Wikipedia. Wikimedia Foundation. Web. https://en.wikipedia.org/wiki/Memory

8. "How to Improve Memory Power: 10 Tips and Tricks - NDTV Food." Food.ndtv.com. Web. http://food.ndtv.com/health/how-to-improve-memory-power-10-tips-and-tricks-1229718

9. "7 Techniques to Help Improve Your Memory." Mercola.com. Web. http://articles.mercola.com/sites/articles/archive/2014/04/24/memory-improvementtricks.aspx

How to cite this article: P Kelasi (2016), The Method of Learning and Its Effect on Memory, International Journal of Indian Psychology, Volume 3, Issue 3, No. 10, DIP: 18.01.188/20160303, ISBN: 978-1-365-19879-3

(C) The International Journal of Indian Psychology, ISSN 2348-5396 (e)| ISSN: 2349-3429 (p) | 155 